\title{
Purification, Characterization and De-Staining Potentials of a Thermotolerant Protease Produced by Fusarium oxysporum
}

\author{
Mohammed Inuwa Ja'afaru', Konjerimam Ishaku Chimbekujwo', Obinna Markraphael Ajunwa ${ }^{1 *}$ \\ 1 Department of Microbiology, School of Life Sciences, Modibbo Adama University of Technology, \\ P.M.B. 2076, Yola, Adamawa State, Nigeria \\ *Corresponding author, e-mail: obinna.ajunwa@mautech.edu.ng
}

Received: 07 June 2019, Accepted: 04 September 2019, Published online: 14 October 2019

\begin{abstract}
Proteases are important industrial enzymes and fungi prove to be good sources of such enzymes. Purification techniques are however necessary for increased specificity in activity and better industrial value. Based on this, a protease produced by a Fusarium oxysporum was purified to homogeneity by Sephadex G-200 column and a-casein agarose chromatography. The enzyme had a molecular weight of $70 \mathrm{kDa}$ in SDS-PAGE. Purified Fusarium oxysporum protease had a specific activity of $93.88 \mathrm{U} / \mathrm{mg}$ protein. The purification magnitude was 7.7 and the total yield was $20 \%$. Purified protease had an optimum pH of 5.0 while the optimum temperature was $40{ }^{\circ} \mathrm{C}$. The enzyme was also thermotolerant (approximately $100 \%$ at $40{ }^{\circ} \mathrm{C}$ for $2 \mathrm{~h}$ ). The enzyme activity was stimulated by surfactants and metal ions like, Tween-20 and $\mathrm{Mg}^{2+}$. Enzyme activity was inhibited in presence of PMSF and EDTA. Casein was found to be the best substrate for protease activity of Fusarium oxysporum FWT1. Protease were tested upon blood stain for de-clotting of blood and was found to exhibit good de-clotting and de-staining activity after 15 minutes treatment time.
\end{abstract}

Keywords

Fusarium oxysporum, protease, enzyme purification, thermotolerant

\section{Introduction}

Proteases are degradative enzymes, which catalyze the total hydrolysis of proteins. Microbial proteases are proteases from microorganisms and are very important in the global enzyme trade, as they account for up to $60 \%$ of the total enzyme merchandise [1]. Proteases as important industrial enzymes can be incorporated in detergents, therapeutics, food industries, leather, meat processing and cheese making [2-4]. Considering the industrial importance of microbial enzymes and to fulfill the constant need of proteases, new enzymes for use in commercial applications with desirable biochemical and physiochemical characteristics and low production cost have been the focus of much research $[2,5]$.

Fungi produce a wide variety of proteolytic enzymes depending on the specie and the environment, with filamentous fungi having potentials to grow and produce enzymes under varying environmental and physiological conditions [6]. Some of these factors such as production time course, metallic ions, surfactants, inhibitors, $\mathrm{pH}$ and temperature, utilizing a wide variety of substrates as nutrients are important in characterization of fungal proteases [2]. However, the major criteria for proteases selection are based on the $\mathrm{pH}$ activity as well as their thermal stability [2, 7]. Fungal proteases have been a major important commodity in industrial enzyme production and have been applied hydrolytically on a variety of proteinaceous systems [7, 8].

As a key factor of bioresource sustainability, fungal proteases have been accorded some major regard because of the ability of fungi to proliferate on inexpensive substrates while excreting copious amounts of enzymes into the surrounding nutrient medium [8]. The efficiency of fungal protease production as well as its catalytic properties have been identified to be specie specific as fungal genera like Aspergillus, Penicillium, Fusarium and Rhizopus have been identified as good sources of proteases [8]. A report by [9] showed that Fusarium oxysoprum was implicated as one of the abundant fungal species with a good proteolytic potential, with enzymes from $F$. oxysporum strains showing a good deal of thermotolerance [7, 9]. F. oxysporum proteases have also been proven to catalytically attack a variety of unique substrates with proteinacous components like rice bran and chitin with a high efficiency level 
$[9,10]$, thereby making them microorganisms of choice in protease production.

The present study focused on purification, characterization and application of the protease produced by a Fusarium oxysporum isolate using wheat bran as substrate, with the possibility of opening up a path in its industrial scale production and application.

\section{Materials and methods}

\subsection{Microorganism}

The test microorganism was a thermotolerant protease producing fungal isolate coded as FWT1, which was earlier isolated from a refuse waste dump site in Jimeta, Yola, Nigeria $\left(9.2035^{\circ} \mathrm{N}, 12.4954^{\circ} \mathrm{E}\right)$. Following molecular characterization using ITS sequence, the fungi was identified as a Fusarium oxysporum FWT1 (NCBI assession number MF599163.1). The strain is stored in the culture bank of the Department of Microbiology, Modibbo Adama University of Technology.

\subsection{Protease production}

Ten grams of substrate (wheat bran) was moistened with salt solution [composed of $(\% \mathrm{w} / \mathrm{v})$ : $\mathrm{NH}_{4} \mathrm{NO}_{3} 0.5$, potassium dihydrogen orthophosphate $0.2, \mathrm{NaCl} 0.1$ and $\mathrm{MgSO}_{4}$ $0.1]$, with trace elements: $\mathrm{ZnSO}_{4} \cdot 7 \mathrm{H}_{2} \mathrm{O}$ and $\mathrm{FeSO}_{4} \cdot 7 \mathrm{H}_{2} \mathrm{O}$; $0.01 \mathrm{ml}$ of each and sterilized at $121.5{ }^{\circ} \mathrm{C}$ for $15 \mathrm{~min}$, cooled, inoculated with $1 \mathrm{ml}$ of $10^{6}$ spore suspension of F. oxysporum and incubated at $28^{\circ} \mathrm{C}$ for 7 days [11].

\subsection{Enzyme extraction}

One milliliter of Tween 80 was added in $100 \mathrm{ml}$ of distilled water. $100 \mathrm{ml}$ of the solution was added into the fermented substrate and was homogenized on a rotary shaker at $150 \mathrm{rpm}$ for 1 hour. The solution was then filtered and the solids were removed by centrifuging the homogenate at 3,500 x g for $15 \mathrm{mins}$ at $4{ }^{\circ} \mathrm{C}$. The resultant supernatant was used for analytical studies [11].

\subsection{Assay of protease activity}

Total protease activity in culture supernatant was measured according to the procedure stated by Keay and Wildi [12] with minor modifications using casein as substrate. One milliliter of $1 \%(\mathrm{w} / \mathrm{v})$ casein in $0.1 \mathrm{M}$ sodium phosphate buffer ( $\mathrm{pH} 7.0$ ) was mixed with $1 \mathrm{ml}$ of culture supernatant. The mixture was then incubated for $10 \mathrm{~min}$ at $30^{\circ} \mathrm{C}$ and the reaction was terminated by addition of $2 \mathrm{ml}$ of $0.4 \mathrm{M}$ trichloroacetic (TCA) acid. The mixture containing the culture supernatant was then incubated for $30 \mathrm{~min}$ at room temperature followed by centrifugation at $11,000 \mathrm{x}$ g for $5 \mathrm{~min}$. The resultant supernatant $(1 \mathrm{ml})$ was then mixed with $5.0 \mathrm{ml}$ of $0.4 \mathrm{M}$ $\mathrm{Na}_{2} \mathrm{CO}_{3}$ and after $10 \mathrm{~min}, 1 \mathrm{ml}$ of Folin reagent mixed with $3 \mathrm{ml}$ of distilled water $(1: 3 \mathrm{v} / \mathrm{v})$ was added to each tube. The tubes were allowed to stand for $30 \mathrm{~min}$ at $30^{\circ} \mathrm{C}$ and then the absorbance was measured at $660 \mathrm{~nm}$. This similar method was used to prepare the control. However, casein was added only after the reaction was stopped. A standard curve was generated using $0-60 \mu \mathrm{g} / \mathrm{ml}$ of tyrosine. One unit of protease activity was defined as the amount of enzyme required to liberate one microgram $(1 \mu \mathrm{g} / \mathrm{ml})$ of tyrosine under the assay conditions described.

\subsection{Protein estimation}

Protein was determined by the method of Lowry [13] using bovine serum albumin (BSA) as the standard.

\subsection{Purification of enzyme}

All purification steps were carried out at $4{ }^{\circ} \mathrm{C}$.

\subsubsection{Ammonium sulfate precipitation}

Protein precipitation by salting out technique was carried out using ammonium sulfate fractionation with constant and gentle stirring. Two ammonium sulfate precipitation steps were performed in the preparation of enzyme concentrate. The crude enzyme was first saturated up to $30 \%$ (with $17.9 \mathrm{~g}$ ammonium sulfate) and then centrifuged at $11,000 \mathrm{x} g$ at $4{ }^{\circ} \mathrm{C}$ for $10 \mathrm{~min}$. The supernatant was separated from the pellet, then, the pellet was re-suspended in minimal volume of $0.1 \mathrm{M}$ phosphate buffer $(\mathrm{pH} 7)$. Approximately $80 \%$ saturation of the separated supernatant was achieved by a slow addition of $52.5 \mathrm{~g}$ of ammonium sulfate based on the volume of the supernatant and stirred at cooled condition for an hour. The solution was subsequently transferred into a centrifuge tube and centrifuged at $11,000 \mathrm{x} \mathrm{g}$ for $5 \mathrm{~min}$. The final supernatant was discarded and the pellet or precipitate was collected and pooled with the first pellet portion earlier obtained and resuspended in minimal volume of $0.1 \mathrm{M}$ phosphate buffer; pH 7 [14]. The extracts were tested for protease activity and protein content.

\subsubsection{Dialysis}

A cellulose acetate dialysis tube was treated to remove protectants such as sulfur and glycerin compounds present in it. The treatment of the tube was achieved by boiling the tube in $2 \%$ sodium bicarbonate for 10 minutes to remove sulphides. It was rinsed once in distilled water and 
again boiled in $10 \mathrm{mM}$ EDTA solution for 10-20 minutes to remove metals. The tube was cooled and washed extensively in distilled water and stored at $4{ }^{\circ} \mathrm{C}$. One end of the dialysis tube was closed using leak proof clamps. The enzyme product from the ammonium sulphate precipitation were introduced into a cellulose-based dialysis tubing. The other end of the dialysis tube was clamped while keeping sufficient space above the sample and placed in a beaker. The solution was dialyzed against $500 \mathrm{ml}$ of the same buffer for 12 hours at $4{ }^{\circ} \mathrm{C}$ in a refrigerator to remove the excess salt with one change after $4 \mathrm{~h}$. This was followed by centrifugation of the resulting solution at $12,500 \mathrm{x} g$ at $4{ }^{\circ} \mathrm{C}$ and the supernatant was tested for protease activity and protein concentration [15].

\subsubsection{Gel filtration}

Sephadex G-200 gel was used to further purify the protease enzyme. Preparation of the gel column and the fractionation procedure was as described by Souza et al. [16]. The gel was equilibrated with $0.1 \mathrm{M}$ phosphate buffer of pH 7.0 and the slurry was allowed to swell overnight at room temperature. Sodium azide $(0.02 \%)$ was added to prevent microbial growth. The gel was packed unto a column $(2.6 \times 40 \mathrm{~cm})$ and equilibrated with $0.1 \mathrm{M}$ phosphate buffer of $\mathrm{pH}$ 7.0. The enzyme solution was collected and dissolved in phosphate buffer $0.1 \mathrm{M}, \mathrm{pH} 7.0$ and fractionated through the Sephadex G - 200 column. Seven milliliters of the enzyme preparation was applied carefully to the top of the gel and allowed to pass into the gel by running the column. Buffer was added without disturbing the gel surface and the reservoir. Elution was carried out with the respective buffer at a flow rate of $20 \mathrm{ml} / \mathrm{h}$. Twenty fractions ( $5 \mathrm{ml}$ each) were collected and each fraction was analyzed for protein concentration and protease activity. The eluted enzymatically active fractions were pooled and used as the partially purified enzyme [17].

\subsubsection{Alpha-casein agarose affinity chromatography}

For further purification of the sepharose gel filtered sample, it was subjected to purification by alpha-casein agarose gel column chromatography. Preparation of the column and the fractionation procedure was as described by Kocabiyik and Ozdemir [18]. Phosphate buffer ( $\mathrm{pH}$ 7.0) was used. Five grams of $\alpha$-casein agarose was suspended in $0.1 \mathrm{M}$ phosphate buffer and kept overnight for equilibration. The column $(2.6 \times 40 \mathrm{~cm})$ was carefully packed and equilibrated with the buffer. Three milliliters of the partially purified enzyme extract was diluted to $15 \mathrm{ml}$ and loaded onto the column and was washed with approximately $100 \mathrm{ml}$ of the equilibration buffer. Proteins was eluted with phosphate buffer $\mathrm{pH} 7.0$ and $\mathrm{NaCl}$ gradient 0.1-1 M, was passed through the exchanger at a flow rate of $30 \mathrm{ml} / \mathrm{h}$. Five milliliters fractions were collected. The eluted fractions were collected and each fraction was analyzed for protein concentration and protease activity and the active fractions were pooled together.

\subsubsection{Determination of molecular weight}

Sodium dodecyl sulphate-polyacrylamide gel electrophoresis (SDS-PAGE) was carried out according to the method suggested by Laemmli [19]. Electrophoresis was performed in a mini- slab gel using $5 \%$ stacking gel and $10 \%$ separating gel. Sample was mixed with sample buffer containing SDS and $\beta$-mercaptoethanol and heated at $100{ }^{\circ} \mathrm{C}$ for $5 \mathrm{~min}$ in water bath before electrophoresis. Electrophoresis was performed at $50 \mathrm{~V}$ for stacking gel and $100 \mathrm{~V}$ for separating gel. Protein bands was visualized after staining the gel with $0.25 \%$ Coomassie Brilliant Blue R250 in $30 \%$ ethanol- $10 \%$ acetic acid for $20 \mathrm{~min}$ and destained with $30 \%$ ethanol-10\% acetic acid. The molecular weight of protein bands was determined by comparing with the bands of standard molecular mass markers [20].

\subsection{Characterization of purified enzyme}

\subsubsection{Effect of $\mathrm{pH}$ on activity and stability of protease}

The effect of $\mathrm{pH}$ on the enzyme activity of protease was determined with casein $(1 \% \mathrm{w} / \mathrm{v})$ as substrate by measuring the enzyme activity at varying $\mathrm{pH}$ values ranging from 4 to 10 at $40{ }^{\circ} \mathrm{C}$ for 10 min using different buffer systems: $0.1 \mathrm{M}$ sodium acetate buffer $(\mathrm{pH} 4.0-5.0) ; 0.1 \mathrm{M}$ sodium phosphate buffer (6.0-7.0); tris - $\mathrm{HCl}$ buffer ( $\mathrm{pH} 8.0)$ and a glycine $-\mathrm{NaOH}$ buffer ( $\mathrm{pH} 9.0-10.0$ ). The $\mathrm{pH}$ stability studies were performed by pre-incubating the purified enzyme without substrate in $\mathrm{pH}$ values ranging from 4.0 10.0 at $40{ }^{\circ} \mathrm{C}$ for 2 hours and the residual proteolytic activity was determined under standard assay conditions [21].

\subsubsection{Effect of temperature on activity and stability of protease}

The effect of temperature on protease activity was determined by estimating the protease activity at $\mathrm{pH} 5.0$ within a temperature range of $30-60{ }^{\circ} \mathrm{C}$ for 2 hours using casein as substrate. The thermal stability of the protease was determined by pre-incubation of crude enzyme preparation $\left(\mathrm{pH} \mathrm{5.0)}\right.$ at different temperatures $\left(30-60{ }^{\circ} \mathrm{C}\right)$ for 30 
min without substrate. The residual proteolytic activity was determined under standard assay conditions [21].

\subsubsection{Effect of metal ions on enzyme activity}

The effects of various metal ions $(5 \mathrm{mM})$ on enzyme activity was determined by pre-incubating the enzyme preparation for 30 minutes at $25{ }^{\circ} \mathrm{C}$ in different ionic solutions: $\mathrm{CaCl}_{2} \cdot 7 \mathrm{H}_{2} \mathrm{O} \quad\left(\mathrm{Ca}^{2+}\right), \quad \mathrm{MgSO}_{4} \cdot 7 \mathrm{H}_{2} \mathrm{O}\left(\mathrm{Mg}^{2+}\right), \quad \mathrm{MnSO}_{4} \cdot 7 \mathrm{H}_{2} \mathrm{O}$ $\left(\mathrm{Mn}^{2+}\right), \quad \mathrm{FeSO}_{4} \cdot 7 \mathrm{H}_{2} \mathrm{O}\left(\mathrm{Fe}^{3+}\right), \quad \mathrm{CuSO}_{4} \cdot 7 \mathrm{H}_{2} \mathrm{O}\left(\mathrm{Cu}^{2+}\right)$ and $\mathrm{ZnSO}_{4} \cdot 7 \mathrm{H}_{2} \mathrm{O}\left(\mathrm{Zn}^{2+}\right)$. Thereafter, protease assay was performed at $40{ }^{\circ} \mathrm{C}$ and $\mathrm{pH}$ 5.0. Relative activity was determined by considering the activity of the enzyme without any metallic ions as $100 \%$. All experiments were conducted in triplicates and their mean values presented [21].

\subsubsection{Effect of inhibitors on enzyme activity}

Protease type was determined by employing the following inhibitors: ethylenediaminetetraacetic acid (EDTA) and phenylsulfonyl fluoride (PMSF). Protease was pre-incubated with each inhibitor, $5.0 \mathrm{mM}$, in $100 \mathrm{mM}$ acetate buffer (pH 5.0) for $30 \mathrm{~min}$ at $40^{\circ} \mathrm{C}$. The control was pre-incubated without any inhibitor and the residual activity was calculated [22].

\subsubsection{Effect of surfactants on enzyme stability}

The effect of surfactants: $1 \%$ sodium dodecyl sulphate (SDS), Tween-20 (Polyoxy ethylene sorbitanmonooleate), Tween-80 (polyethylene glycol sorbitanmonooleate) and Triton X-100 (trioctylphenoxypolyethoxyethanol) on the proteolytic activity was determined by pre-incubating enzyme for $1 \mathrm{~h}$ in the above surfactants at $40{ }^{\circ} \mathrm{C}$ and pH 5.0 before assaying for the residual enzyme activity. A control was kept with the enzyme and the substrate without detergents and the value of the control activity was considered as $100 \%$ [23].

\subsection{Substrate specificity of protease}

Protease activity with various protein substrates including bovine serum albumin (BSA), casein, egg albumin and gelatin was assayed by mixing $1 \mathrm{ml}$ of enzyme and $2 \mathrm{ml}$ of assay buffer (acetate buffer, $0.5 \mathrm{M}, \mathrm{pH} 5$ ) containing protein substrate $(2 \mathrm{mg} / \mathrm{ml})$. After incubation at $40{ }^{\circ} \mathrm{C}$ for 30 minute with each of the substrates separately, enzyme activity was measured [24].

\subsection{Application of protease}

The de-staining property was studied by applying human blood on four pieces of clean white cloth $(5 \mathrm{~cm} \mathrm{x} 7 \mathrm{~cm})$ and allowed to air dry for $15 \mathrm{~min}$. The stained cloth pieces were taken into four different flasks as described by Kunamneni et al. [25]. The first flask was prepared with $100 \mathrm{ml}$ of distilled water, stained cloth and $1 \mathrm{ml}$ of detergent $(7 \mathrm{mg} / \mathrm{ml})$. The second was prepared with $100 \mathrm{ml}$ of distilled water, stained cloth and $1 \mathrm{ml}$ of enzyme extract. The third was prepared with $100 \mathrm{ml}$ of water, stained cloth, $1 \mathrm{ml}$ of detergent $(7 \mathrm{mg} / \mathrm{ml})$ and $1 \mathrm{ml}$ of enzyme extract. The last flask was prepared with $100 \mathrm{ml}$ of distilled water and stained cloth as negative control. The flasks were incubated at $40{ }^{\circ} \mathrm{C}$ for 15 minutes. After incubation, cloth pieces were taken out, rinsed with water, and dried. Visual examination of various pieces showed the effect of enzyme in the removal of stains.

\section{Results and discussion}

\subsection{Purification of protease}

A 7.7 - fold purification was achieved with $20 \%$ recovery of protease activity, yielding a specific activity of 93.88 U/mg protein. The result obtained in this research as shown in Table 1 present an $11 \%$ yield. This value was higher than the yield reported for the fibrinolytic enzyme from a Fusarium culmorum [26]. The purified enzyme preparation appeared as a single protein with a molecular weight of $70 \mathrm{kDa}$ (Fig. 1). In variance to our findings, the molecular weight of the F. oxysporum FWT1 protease was higher than that reported by Ricardo et al. [27], Pekkarinen et al. [26] and Wu et al. [28] having a molecular mass of 41, 28.7 and $28 \mathrm{kDa}$ for purified protease by Fusarium culmorum, Fusarium oxysporum var iini and Fusarium sp. respectively. Griffen et al. [29] also reported that aspartic protease by $F$. graminearum had molecular mass of $40 \mathrm{kDa}$.With respect to results obtained, a similar protein size of $70 \mathrm{kDa}$ on SDS-PAGE was reported by $\mathrm{Na}$ and Liang [30].

Table 1 Purification steps of protease produced by Fusarium oxysporum

\begin{tabular}{cccccc}
\multicolumn{7}{c}{ FWT1 } \\
\hline $\begin{array}{c}\text { Purification } \\
\text { steps }\end{array}$ & $\begin{array}{c}\text { Enzyme } \\
\text { activity } \\
(\mathrm{U} / \mathrm{ml})\end{array}$ & $\begin{array}{c}\text { Total } \\
\text { protein } \\
(\mathrm{mg})\end{array}$ & $\begin{array}{c}\text { Specific } \\
\text { activity } \\
(\mathrm{U} / \mathrm{mg})\end{array}$ & $\begin{array}{c}\text { Yield } \\
\%\end{array}$ & $\begin{array}{c}\text { Purification } \\
\text { fold }\end{array}$ \\
\hline $\begin{array}{c}\text { Crude enzyme } \\
\text { extract }\end{array}$ & $1826 \pm 2.0$ & $150 \pm 2.5$ & $12.17 \pm 1.62$ & 100 & 1.0 \\
$\begin{array}{c}\text { Ammonium } \\
\text { precipitation }\end{array}$ & $486 \pm 1.0$ & $21 \pm 1.0$ & $23.14 \pm 1.78$ & 27 & 1.9 \\
$\begin{array}{c}\text { Dialysis } \\
\text { Sephadex } \\
\text { G-200 }\end{array}$ & $482 \pm 2.0$ & $17 \pm 1.5$ & $29.35 \pm 2.5$ & 26 & 2.4 \\
$\begin{array}{c}\alpha-\text { casein } \\
\text { agarose }\end{array}$ & $375 \pm 0.5$ & $4.0 \pm 0.3$ & $93.88 \pm 2.71$ & 20 & 7.7 \\
\hline
\end{tabular}




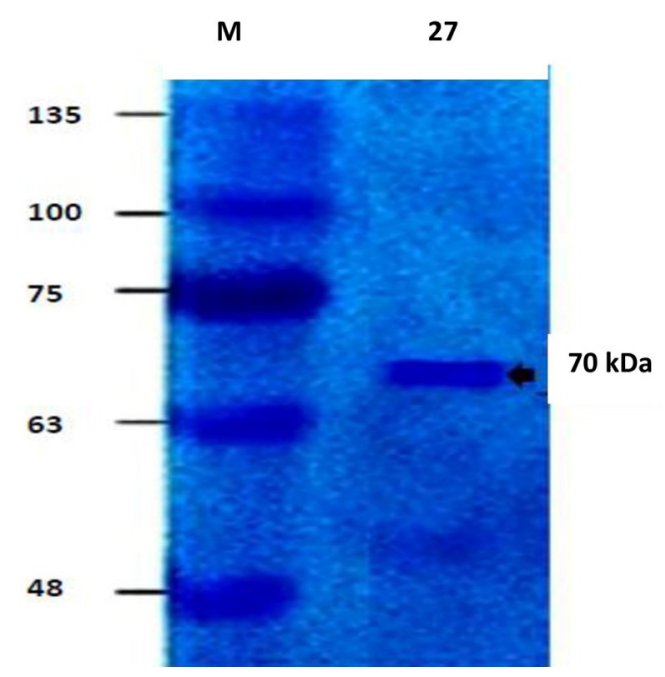

Fig. 1 SDS PAGE of purified protease. M: molecular mass maker, Lane 27: purified protease of Fusarium oxysporum FWT1.

\subsection{Characterization of the purified enzyme}

\subsubsection{Effect of pH on enzyme activity and stability of} protease

The optimum $\mathrm{pH}$ of purified protease was at pH 5 (100\%). Protease activity decreased as the $\mathrm{pH}$ increased from pH 6-9 with the least activity at pH 10 (Fig. 2). Fungal proteases are reported to be active over a wide $\mathrm{pH}$ range ( $\mathrm{pH} 4.0$ to 11.0) [31], the enzyme produced however appeared to be slightly acid. Fungi have been characterized as good producers of acid proteases [32], with the enzymes showing optimal $\mathrm{pH}$ between 4.0 and 5.0 [33]. Adejuwon and Olutiola [34] in their work reported optimum $\mathrm{pH}$ for protease activity at 6 by Fusarium oxysporum. $\mathrm{pH}$ stability at wide range of $\mathrm{pH}$ is a desirable property of any enzyme for industrial application. Pekkarinen et al. [26] reported that the enzyme was active at $\mathrm{pH} 8.3-$ 9.6 by F. culmorum. A pH of 5 has been reported to be the optimum $\mathrm{pH}$ for other fungal protease such as those of Aspergillus sp. and Chaetomium thermophilum [24, 35].

\subsubsection{Effect of temperature on enzyme activity and stability of protease}

The result shown in Fig. 3 indicates $40{ }^{\circ} \mathrm{C}(100 \%)$ as the optimum temperature of activity for the purified protease. Further increase in temperature was detrimental to enzyme activity with the least activity at $60^{\circ} \mathrm{C}$. Reports by Adejuwon and Olutiola [34] had corroborated our observations as temperature values of $35-40{ }^{\circ} \mathrm{C}$ had been shown to be optimal for Fusarium spp. protease produced. The enzyme displayed good stability over temperatures ranging from $30-40^{\circ} \mathrm{C}$; the optimum temperature was found to

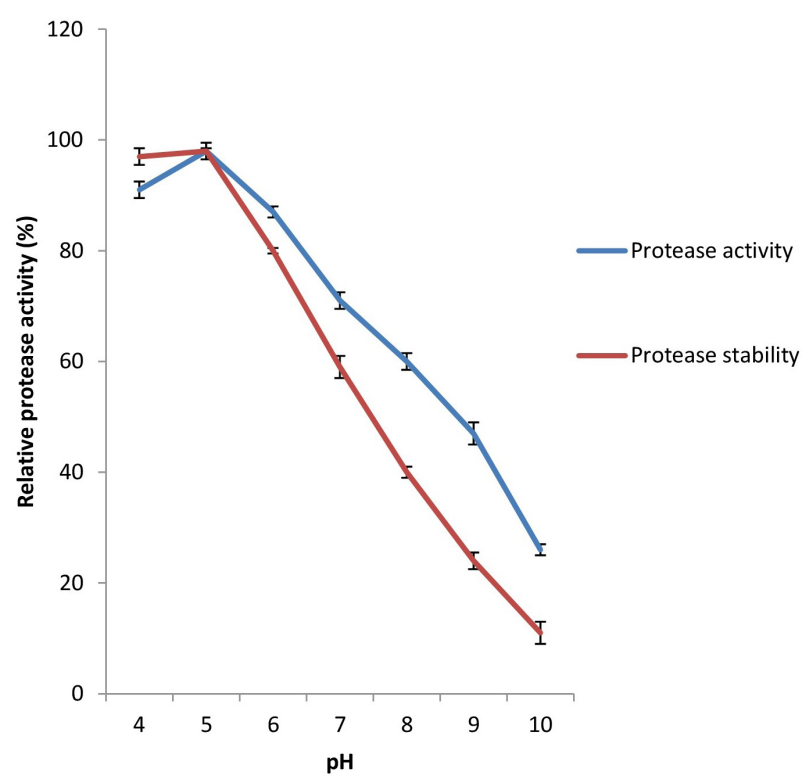

Fig. 2 Effect of $\mathrm{pH}$ on the activity and stability of purified protease from Fusarium oxysporum FWT1

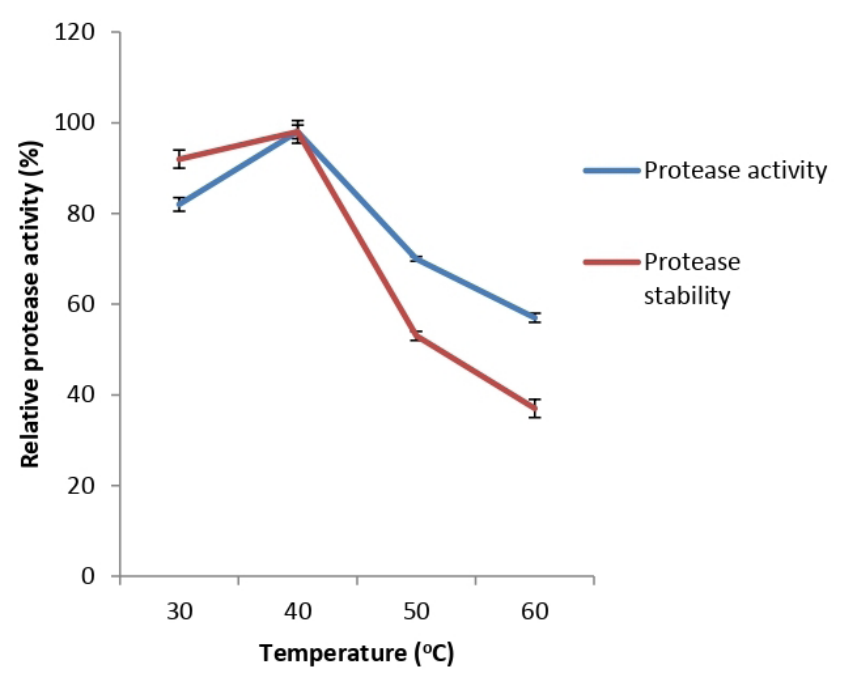

Fig. 3 Effect of temperature on the activity and stability of purified protease from Fusarium oxysporum FWT1

be $40{ }^{\circ} \mathrm{C}$ while at $30{ }^{\circ} \mathrm{C}$ it showed $92 \%$ proteolytic activity. The residual activity of the enzyme showed a sharp decrease in proteolytic activity between 40 and $60{ }^{\circ} \mathrm{C}$ (37\%) as the temperature increased. Pekkarinen et al. [26] also reported enzyme stability at $50{ }^{\circ} \mathrm{C}$ by Fusarium culmorum, a value higher than as observed in our experiments. Variations in temperature stabilities could be strain specific and specific enzyme properties molecular characteristics could reveal further these variation. Proteases from other fungi like Aspergillus carneus, Penicillium janthinellum and Aspergillus tamarii showed optimum stability at $40{ }^{\circ} \mathrm{C}[14,36-38]$ but unstable at temperatures above $40^{\circ} \mathrm{C}$. Overall, the temperature optima and stability profile 
of the purified protease suggested that the enzyme could be a viable option for industrial application.

\subsubsection{Effect of metal ions on the activity of protease}

The effect of various metal ions on enzyme activity result is presented in Table 2. It showed that under the metal ion $\mathrm{Mg}^{2+}$ the enzyme was stable with no noticeable reduction in its activity. The effect of $\mathrm{Cu}^{2+}$ which elicited a $28 \%$ relative protease activity compared with the control showed there was a drastic reduction in enzyme activity as $\mathrm{Cu}^{2+}$ was the most potent inhibitor of protease. The result obtained in this research was in conformity with the earlier findings of Adejuwon and Olutiola [34] which showed enhancement of protease activity in the presence of $\mathrm{Ca}^{2+}$ and $\mathrm{Mg}^{2+}$ by Fusarium spp. Reports by Namrata and Kantishree [39] and Ricardo et al. [27] for Aspergillus tamari and Fusarium oxysporum were also in conformity with our data. This is because the metal ions had been stated as viable stability enhancers of proteases. The ions $\mathrm{Ca}^{2+}$ and $\mathrm{Mg}^{2+}$ are involved in stabilizing the active structure, but they are not needed for the catalytic function or for the protein chain folding process to form the active structure $[40,41]$. Based on metal ion interaction with other enzymes, it had also been identified that $\mathrm{Cu}^{2+}$ and $\mathrm{Co}^{+2}$ had inhibitory effects on metallo fibrinolytic enzymes of Fusarium spp. [28] having a direct correlation with our results for $\mathrm{Cu}^{2+}$.

\subsubsection{Effect of inhibitors and surfactants on the activity of protease}

The effect of inhibitors and surfactants on enzyme activity studied is as shown in Table 3. It was noted that Tween20 and Tween-80 (100 and 95\%) had no effect on protease activity while inhibition of enzymatic activity was most noticed for EDTA and PMSF (26 and $36 \%$ of residual activity respectively). Inhibitory effects of PMSF were also reported by Pekkarinen et al. [26], Namrata, and

Table 2 Effect of Metal ion on the activity of purified protease from Fusarium oxysporum FWT1

\begin{tabular}{cc}
\hline Metal ion Source & Relative protease activity (\%) \\
\hline $\mathrm{Control}$ & 100 \\
$\mathrm{MnSO}_{4}\left(\mathrm{Mn}^{2+}\right)$ & 52 \\
$\mathrm{FeSO}_{4}\left(\mathrm{Fe}^{2+}\right)$ & 41 \\
$\mathrm{CuSO}_{4}\left(\mathrm{Cu}^{2+}\right)$ & 28 \\
$\mathrm{ZnSO}_{4}\left(\mathrm{Zn}^{2+}\right)$ & 51 \\
$\mathrm{MgSO}_{4}\left(\mathrm{Mg}^{2+}\right)$ & 100 \\
$\mathrm{CaCl}_{2}\left(\mathrm{Ca}^{2+}\right)$ & 84 \\
\hline
\end{tabular}

Kantishree [39] and Sharma and Kantishree [22] using Fusarium culmorum, Rhizopus microsporus NRRL3671 and Aspergillus tamarii [EF661565.1]. They also further concretized their findings by stating that their inhibition by PMSF suggested that these enzymes were serine proteases. It is an observable fact that surfactants alter cell permeability of microorganisms thereby leading to increased protein secretion or surface effects on cell-bound enzymes [42]. Due to their specificity, inhibitors and surfactants can also aid in characterization of novel proteases by examining hydrolysis rates of protease in their presence [17].

\subsubsection{Effect of different substrates on the activity of protease}

Protease activity measured under the influence of various substrates including bovine serum albumin, casein, gelatin and egg albumin is as shown in Table 4. Casein $(100 \%)$ was found to be the best substrate for protease activity with the least proteolytic activity observed by bovine serum albumin (49\%). Similar reports of a preference for caseinolysis over other substrates had been stated for Aspergillus niger [17]. The purified protease could hydrolyze all substrates tested but showed higher specificity to casein hydrolysis than the other three substrates. The important feature of proteases is their ability to discriminate among competing substrates and utility of these enzymes often depends on their substrate specificity $[43,44]$. The substrate specificity profile of the purified protease indicated that the enzyme had a broad range of hydrolytic activity on various protein substrates which shows a great potential in biotechnological applications.

Table 3 Effect of surfactants and inhibitors on protease activity

\begin{tabular}{cc}
\hline Surfactants and Inhibitors & Relative protease activity (\%) \\
\hline SDS & 66 \\
Tween 20 & 100 \\
Tween 80 & 95 \\
Triton X-100 & 91 \\
EDTA & 26 \\
PMSF & 36 \\
Control & 100 \\
\hline Table 4 Effect of different substrates on the activity of protease \\
\hline Substrate & Relative protease activity (\%) \\
\hline Casein & 100 \\
Bovine serum albumin & 49 \\
Egg albumin & 87 \\
Gelatin & 69
\end{tabular}




\subsection{Application of protease in de-staining (Washing tests)}

The de-staining studies gave good results on the cotton cloths stained with human blood (Fig. 4). There was still an evident blood stain in the cloth washed with only water (A). However, de-staining effects were observed for the other cloth samples treated with detergent solution alone (C), detergent mixed with enzyme (B), and enzyme alone (D). The enzyme used was the purified form $(1 \mathrm{ml}$; $375 \pm 0.05 \mathrm{U} / \mathrm{ml}$ ), and these results showed the effectiveness of the extracted protease in proteinaceous stain removal. This indicates that the protease enzyme obtained from this isolate could be considered as a potential candidate for use as cleaning agent to facilitate the release of proteinaceous stains and also of great significance in textile industries. Studies on the usefulness of proteases from fungi were reported [45] in the facilitation of blood stains removal from cotton cloth both in the presence and absence of detergents.

\section{Conclusion}

In this present study, protease produced by Fusarium oxysporum was purified to 7.7 fold with a yield of $20 \%$. The molecular weight of the purified enzyme was determined to be approximately $70 \mathrm{kDa}$. The enzyme was optimally active and stable at $\mathrm{pH}$ of 5.0 and at $40{ }^{\circ} \mathrm{C}$. This study also highlighted the possibility of co-application of the produced protease with detergent for effective stain removal. Though there were no valid compatibility

\section{References}

[1] Novelli, P. K., Barros, M. M., Fleuri, L. F. "Novel inexpensive fungi proteases: Production by solid state fermentation and characterization", Food Chemistry, 198, pp. 119-124, 2016.

https://doi.org/10.1016/j.foodchem.2015.11.089

[2] Mandal, S., Banerjee, D. "Proteases from Endophytic Fungi with Potential Industrial Application", Recent Advances in White Biotechnology Through Fungi, Fungal Biology, 1, pp. 319-359, 2019.

https://doi.org/10.1007/978-3-030-10480-1_10

[3] Chouyok, W., Wongmongkol, N., Siwarungson, N., Prichnont, S. "Extraction of alkaline protease using two-phase system from cell free Bacillus subtilis TISTR 25 fermentation broth", Process Biochemistry, 40(11), pp. 3514-3518, 2005.

https://doi.org/10.1016/j.procbio.2005.03.052

[4] Rao, M. B., Tanksale, A. M., Ghatge, M. S., Deshpande, V. V. "Molecular and Biotechnological Aspects of Microbial Protease", Microbiology and Molecular Biology Reviews, 62(3), pp. 597-635, 1998. [online] Available at: https://www.ncbi.nlm.nih.gov/pmc/ articles/PMC98927 [Accessed: 12 January 2019]

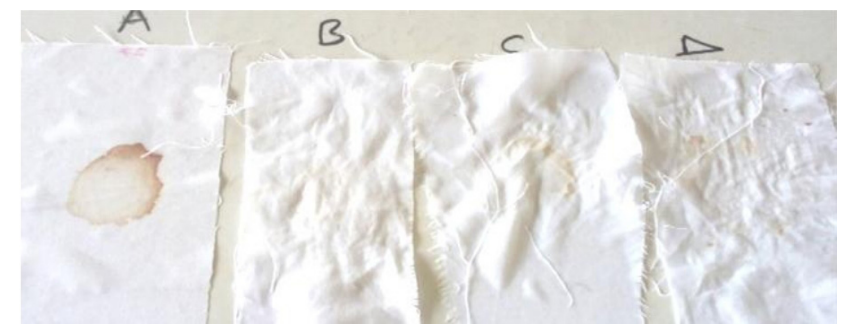

Fig. 4 Blood stain removal using fungal protease and Detergent

assessments carried out with respect to the efficaciousness of the enzyme in combination with the detergent. The de-staining experiments have showed that the enzyme has hydrolytic effects on stains with or without the addition of detergent. Further research is however needed to determine the compatibility levels between the enzyme and detergents of various types based on biochemical and chemical properties, as well as design a variety of effective methods for the application of this enzyme. Fusarium oxysporum FWT1 therefore is a potentially good source of stable enzyme for industrial applications.

\section{Acknowledgement}

The authors are grateful to the Department of Microbiology MAUTECH, Yola, for encouragement and support to write this article. Dr. F. A. Orji and Mr. S. O. Olatope of the Biotechnology Department of the Federal Institute of Industrial Research, Oshodi, Lagos are also acknowledged for technical assistance in enzyme studies.

[5] El-Hassayeb, H. E. A., Abdel-Aziz, S. M. Z. "Screening, Production and Industrial Application of Protease Enzyme from Marine Bacteria", International Journal of Current Microbiology and Applied Sciences, 5(7), pp. 863-874, 2016. https://doi.org/10.20546/ijcmas.2016.507.099

[6] Sarma, K. M., Kumar, R., Panwar, S., Kumar, A. "Microbial alkaline proteases: Optimization of production parameters and their properties", Journal of Genetic Engineering and Biotechnology, 15(1), pp. 115-126, 2017.

https://doi.org/10.1016/j.jgeb.2017.02.001

[7] Razzaq, A., Shamsi, S., Ali, A., Ali, Q., Sajjad, M., Malik, A., Ashraf, M. "Microbial Protease Applications", Frontiers in Bioengineering and Biotechnology, 7(110), pp. 1-20, 2019. https://doi.org/10.3389/fbioe.2019.00110

[8] Maitig, A. M. A., Alhoot, M. A. M., Tiwari, K. "Isolation and Screening of Extracellular Protease Enzyme from Fungal Isolates of Soil", Journal of Pure and Applied Microbiology, 12(4), pp. 2059-2067, 2018. https://doi.org/10.22207/JPAM.12.4.42 
[9] Ali, S. S., Vidhale, N. N. "Protease Production by Fusarium oxysporum in Solid-State Fermentation using rice bran", American Journal of Microbiological Research, 1(3), pp. 45-47, 2013. https://doi.org/10.12691/ajmr-1-3-2

[10] Jashni, M. K., Dols, I. V. M., Iida, Y., Boeren, S., Beenen, H. G., Mehrabi, R. "Synergistic Action of a Metalloprotease and a Serine Protease from Fusarium oxysporum f. sp. lycopersici Cleaves Chitin-Binding Tomato Chitinases, Reduces Their Antifungal Activity, and Enhances Fungal Virulence", Molecular PlantMicrobe Interactions, 28(9), pp. 996-1008, 2015. https://doi.org/10.1094/MPMI-04-15-0074-R

[11] Xiao, Y. Z., Wu, D. K., Zhao, S. Y., Lin, W. M., Gao, X. Y. "Statistical Optimisation of Alkaline Protease Production from Penicillium citrinum YL-1 Under Solid-State Fermentation", Preparative Biochemistry and Biotechnology, 45(5), pp. 447-462, 2014.

https://doi.org/10.1080/10826068.2014.923450

[12] Keay, L., Wildi, B. S. "Proteases of the genus Bacillus, I. Neutral proteases", Biotechnology and Bioengineering, 12(2), pp. 179-212, 1970. https://doi.org/10.1002/bit.260120205

[13] Lowry, O. H., Rosebrough, N. J., Farr, A. L., Randall, R. J. "Protein measurement with Folin phenol reagent", Journal of Biology and Chemistry, 193(1), pp. 265-275, 1951. [online] Available at: https:// www.ncbi.nlm.nih.gov/pubmed/14907713 [Accessed: 25 February 2019]

[14] Abirami, V., Meenakshi, S. A., Kanthymathy K., Bharathidasan, R., Mahalingam, R., Panneerselvam, A. "Partial Purification and Characterization of an Extracellular Protease from Penicillium janthinellum and Neurospora crassa", European Journal of Experimental Biology, 1(3), pp. 114-123, 2011. [online] Available at: http://www.imedpub.com/european-journal-of-experimental-biology/archive/EJEBAU-volume-1-issue-3-year-2011.html [Accessed: 20 January 2019]

[15] Palanivel, P., Ashokkumar, L., Balagurunathan, R. "Production, Purification and Fibrinolytic Characterization of Alkaline Protease from Extremophilic Soil Fungi", International Journal of Pharma and Bio Sciences, 4(2), pp. 101-110, 2013. [online] Available at: https://ijpbs.net/counter.php?aid=2234 [Accessed: 16 February 2019]

[16] Souza, P. M., Werneck, G., Aliakbarian, B., Siqueira, F., Filho, E. X. F., Perego, P., Converti, A., Magalhāes, P. O., Junior, A. P. "Production, purification and characterization of an aspartic protease from Aspergillus foetidus", Food and Chemical Toxicology, 109(2), pp. 1103-1110, 2017.

https://doi.org/10.1016/j.fct.2017.03.055

[17] Racheal, , O. O., Ahmed, , A. T. F.,, Ndigwe, E. V., Morakinyo, S. D. "Extraction, Purification and characterization of protease from Aspergillus Niger Isolated from Yam Peels", International Journal of Nutrition and Food Sciences, 4(2), pp. 125-131, 2015. https://doi.org/10.11648/j.ijnfs.20150402.11

[18] Kocabiyik, S., Özdemir, I. "Purification and Characterization of an Intracellular Chymotrypsin-Like Serine Protease from Thermoplasma volcanium", Bioscience, Biotechnology, and Biochemistry, 70(1), pp. 126-134, 2006.

https://doi.org/10.1271/bbb.70.126
[19] Laemmli, U. K. "Cleavages of Structural Proteins during the Assembly of the Head of Bacteriophage T4", Nature, 227, pp. 680685,1970 https://doi.org/10.1038/227680a0

[20] Ferid, A., Aissaoui, N., Lazar, S., Marzouki, M. N. "Purification and biochemical characterization of a novel alkaline protease from Aspergillus niger. Use in antioxidant peptides production", Journal of Materials and Environmental Science, 5(5), pp. 1490-1499, 2014.

[21] Sharma, K. M., Kumar, R., Vats, S., Gupta, A. "Production, partial purification and characterization of alkaline protease from Bacillus aryabhattai K3", International Journal of Advances in Pharmacy, Biology and Chemistry, 3(2), pp. 290-298, 2014. [online] Available at: https://www.ijapbc.com/files/12-3216.pdf [Accessed: 13 February 2019]

[22] Sharma, N., De, K. "Production, purification and crystallization of an alkaline protease from Aspergillus tamari [EF661565.1]", Agriculture and Biology Journal of North America, 2(7), pp. 11351142, 2011.

https://doi.org/10.5251/abjna.2011.2.7.1135.1142

[23] Vijayaraghavan, P., Lavanya, J., Gnana, S., Vincent, P.. "Biosynthesis and characterization of keratinolytic protease from Actinobacterium sp. in solid state culture", International Journal of Applied Biology and Pharmaceutical Technology, 3(4), pp. 149158, 2012.

https://doi.org/10.5251/abjna.2011.2.7.1135.1142

[24] Shivakumar, S. "Production and characterization of an acid Protease from a local Aspergillus Sp. by Solid state fermentation", Archives of Applied Science Research, 4(1), pp. 188-199, 2012. [online] Available at: https://pdfs.semanticscholar.org/73cb/50863da97a402149ce6ffc4992bd0c0153d2.pdf [Accessed: 16 February 2019]

[25] Adinarayana, K., Ellaiah, P., Prasad, D. S. "Purification and partial characterization of thermostable serine alkaline protease from newly isolated Bacillus subtilis PE-11", AAPS PharmSciTech, 4(4), pp. 440-448, 2003.

https://doi.org/10.1208/pt040456

[26] Pekkarinen, A. I., Jones, B. L.,Niku-Paavola, M. L. "Purification and properties of an alkaline proteinase of Fusarium culmorum", European Journal of Biochemistry, 269(3), pp. 798-807, 2002. https://doi.org/10.1046/j.0014-2956.2001.02697.x

[27] Barata, R. A., Guerra Andrade, M. H., Dias Rodrigues, R., Castro, I. M. "Purification and characterization of an extracellular trypsin-like protease of Fusarium oxysporum var. lini", Journal of Bioscience and Bioengineering, 94(4), pp. 304-308, 2002. https://doi.org/10.1016/S1389-1723(02)80168-2

[28] Wu, B., Wu, L., Chen, D., Yang, Z., Luo, M. "Purification and characterization of a novel fibrinolytic protease from Fusarium sp. CPCC 480097", Journal of Industrial Microbiology and Biotechnology, 36(3), pp. 451-459, 2009. https://oi.org/10.1007/s10295-008-0516-5

[29] Griffen, M. A., Wiebe, M. G., Robson, G. D., Trinci, A. P. J. "Extracellular proteases produced by the Quorn ${ }^{\circledR}$ myco-protein fungus Fusarium graminearum in batch and chemostat culture", Microbiology, 143(9), pp. 3007-3013, 1997. https://doi.org/10.1099/00221287-143-9-3007 
[30] Liu, N., Huang, L. "Partial Characterization of an Acidic Protease from Rhizopus stolonifer RN-11", The Open Biotechnology Journal, 9, pp. 199-203, 2015.

https://doi.org/10.2174/1874070701509010199

[31] Kumar, D. J. M., Venkatachalam, P., Govindarajan, N., Balakumaran, M. D., Kalaichelvan, P. T. "Production and Purification of Alkaline Protease from Bacillus sp. MPTK 712 Isolated from Diary Sludge", Global Veterinaria, 8(5), pp. 433439, 2012. [online] Available at: https://idosi.org/gv/GV8(5)12/1. pdf [Accessed: 15 January 2019]

[32] Mefteh, F.B., Frikha, F., Daoud, A., Bouket, A. C., Luptakova, L., Alenezi, F .N., Al-Anzi, B. S., Oszako, T., Gharsallah, N., Belbahri, L. "Response Surface Methodology Optimization of an Acidic Protease Produced by Penicillium bilaiae Isolate TDPEF30, a Newly Recovered Endophytic Fungus from Healthy Roots of Date Palm Trees (Phoenix dactylifera L.)", Microorganisms, 7(3), pp. 74, 2019.

https://doi.org/10.3390/microorganisms7030074

[33] Coral, G., Arikan, B., Ünaldi, M. N., Güvenmez, H. "Thermostable alkaline protease produced by an Aspergillus niger strain", Annals of Microbiology, 53(4), pp. 491-498, 2003. [online] Available at: https://pdfs.semanticscholar.org/ f359/aeeeb60f0daff0be745ca3660a1d8011c305.pdf [Accessed: 10 February 2019]

[34] Adejuwon, A. O., Olutiola, O. P. "Protease in Tomato Fruits Infested by Fusarium oxysporum", Plant Pathology Journal, 4(1), pp. 43-45, 2005.

https://doi.org/10.3923/ppj.2005.43.45

[35] Li, A. N., Ding, A.Y., Chen, J., Liu, S. A., Zhang, M., Li, D. C. "Purification and characterization of two thermostable proteases from the thermophilic fungus Chaetomium thermophilum", Journal of Microbiology and Biotechnology, 17(4), pp. 624-631, 2007. [online] Available at: https://europepmc.org/abstract/ med/18051274 [Accessed: 22 February 2019]

[36] Saxena, R., Singh, R. "Statistical optimization of conditions for protease production from Bacillus sp.", Acta Biologica Szegediensis, 54(2), pp. 135-141, 2010. [online] Available at: https://www2.sci.u-szeged.hu/ABS/2010/Acta\%20HBb/54135.pdf [Accessed: 13 January 2019]

[37] Mushtaq, Z., Irfan, M., Nadeem, M., Naz, M., Syed, Q. "Kinetics Study of Extracellular Detergent Stable Alkaline Protease from Rhizopus oryzae", Brazilian Archives of Biology and Technology, 58(2), pp. 175-184, 2015.

https://doi.org/10.1590/S1516-8913201400071
[38] da Silva,O. S., de Oliveira, R. L., Souza-Motta, C. M., Porto, A. L. F., Porto, T. S. "Novel Protease from Aspergillus tamari URM4634: Production and Characterization Using Inexpensive Agroindustrial Substrates by Solid-State Fermentation", Advances in Enzyme Research, 4, pp. 125-143, 2016. https://doi.org/10.4236/aer.2016.44012

[39] Namrata, S.,De, K. "Production, purification and crystallization of an alkaline protease from Aspergillus tamari [EF661565.1]", Agriculture and Biology Journal of North America, 2(7), pp. 1135$1142,2011$.

https://doi.org/10.5251/abjna.2011.2.7.1135.1142

[40] Anandan, D., Marmer, W. N., Dudley, R. L. "Isolation, characterization and optimization of culture parameters for production of an alkaline protease isolated from Aspergillus tamarii", Journal of Industrial Microbiology and Biotechnology, 34(5), pp. 339-347, 2007.

https://doi.org/10.1007/s10295-006-0201-5

[41] Sakpal, H. C., Narayan, G. "Thermostable alkaline protease from Bacillus sp. and its potential applications", Journal of Pharmacy and Biological Sciences, 10(5), pp. 58-67, 2015.

https://doi.org/10.9790/3008-10515867

[42] Naidu, K. S. B., Devi, K. L. "Optimization of thermostable alkaline protease production from species of Bacillus using rice bran", African Journal of Biotechnology, 4(7), pp. 724-726, 2005. https://doi.org/10.5897/AJB2005.000-3132

[43] Shankar, S., Rao, M., Laxman, R. S. "Purification and characterization of an alkaline protease by a new strain of Beauveria sp", Process Biochemica, 46(2), pp. 579-585, 2011. https://doi.org/10.1016/j.procbio.2010.10.013

[44] Chaubey, P. M., Hofstetter, L., Roschitzki, B., Stieger, B. "Proteomic Analysis of the Rat Canalicular Membrane Reveals Expression of a Complex System of P4-ATPases in Liver", PLOS ONE, 11(6), pp. 1-15, 2016. https://doi.org/10.1371/journal.pone.0158033

[45] Benluvankar, V., Priya, S. E., Gnanadoss, J. J. "Medium Formulation and its optimisation for increased protease production by Penicillium sp. LCJ228 and its potential in blood stain removal", Journal of Applied Biology and Biotechnology, 4(1), pp. 20-26. 2016. https://doi.org/10.7324/JABB.2016.40104 